\title{
BOOK REVIEW - BENTHAM'S THEORY OF FICTIONS
}

\section{Gary Lilienthal, Ph.D.}

\begin{abstract}
This review ${ }^{1}$ is a commentary on Ogden's introduction to Jeremy Bentham's Theory of Fictions. ${ }^{2}$ It tries to show that legal fiction suggests fraud by the user, and more, may well mislead the court. Ogden's introduction separates into five major headings. There is a still a tendency among practising lawyers to speak in pejorative tones about the study of jurisprudence. This tendency may be an indicium of a failure to understand the law's underlying reasoning, and instead, to prefer the law's cultus, ${ }^{3}$ manifesting as fraud and abuse of legislative power. In this view, the reasons are the rules themselves. Therefore, this review addresses Ogden's sections on legal fictions, the vocabulary of fiction, the technique of definition, and fallacies. The review will not discuss Ogden's conclusion or his note on Bentham's method of composition.
\end{abstract}

\section{Legal Fictions}

Ogden reported Bentham's lament that the law remained riddled with tautology, technicality, circuitry, irregularity, and inconsistency. Appearing to group these legal iniquities under the heading of "legal fiction", Bentham defined a "fiction of law" as the saying that something existed which did not exist, and then so acting as if it existed, or vice versa. ${ }^{4}$ Bentham allowed for times when legal fiction would be acceptable. At these times, he advised, its purpose should be achieved directly by the legislature. To understand this, the Rhetorica ad Herennium set out six sources of law: nature; statute; custom; previous judgements; equity; and, agreement. It defined custom as that which in the absence of any statute was by usage endowed with the force of statute law, which it defined as law set up by the sanction of the people. ${ }^{5}$ Thus, the sanction of the people was required for legislation, as a better option than a legal fiction. Otherwise, legal fiction would constitute an assumption of arbitrary power. This would be because it was a falsehood with the sole object of stealing legislative power for the benefit of those who would exercise the legislative power by the creation of rhetorical delusion. ${ }^{6}$

On these bases, Bentham viewed legal fictions as examples of fraud. Legal fictions mainly occurred with common law systems. An example of a legal fiction would be the subsistence of a corporation as a separate legal person. Suggesting Bentham's views of fraud and definition, as below, Narayanan proposed that injury to goodwill could take various forms, including any apprehension of diversion of sales, injurious

\footnotetext{
${ }^{1}$ UUM JLS book reviews should follow the format set out in the University of North Carolina's Writing Centre web page at http://writingcenter.unc.edu/handouts/book-reviews/ . Book review submissions are welcome at any time, on topics of interest to the legal scholarly and practice communities.

${ }^{2}$ CK Ogden, Bentham's Theory of Fictions, reprint from the original 1932 edition, Routledge, Oxford, 2002, pp. ix-clii.

${ }^{3}$ Cultus is used here as meaning the routinized ritual process, evidenced in public loyalty, representing certain inner principles and meanings, performed publicly without reference to those inner meanings. GWF Hegel, Lectures on the Philosophy of Religion, PC Hodgson, ed, RF Brown, PC Hodgson, \& JM Stewart, trans, 3 vols, University of California Press, Berkeley and Los Angeles, 1984-87.

${ }^{4}$ CK Ogden, Bentham's Theory of Fictions, reprint from the original 1932 edition, Routledge, Oxford, 2002, p. xvii.

${ }^{5}$ Cicero, Rhetorica Ad Herennium, Harvard University Press, Cambridge, 2004, pp. 91, 93.

${ }^{6}$ CK Ogden, Bentham's Theory of Fictions, reprint from the original 1932 edition, Routledge, Oxford, 2002, p. xviii.
} 
association, misappropriation of business reputation or misappropriation of personality. ${ }^{7} \mathrm{He}$ stated that each of these was a species of the one genus of unfair trading or unfair competition. He called them "badges" of common law fraud. He proposed that badges of fraud not be species of fraud, but were indicia of fraud, or put another way; they were indicative of fraud. ${ }^{8}$ This proposition arguably reflected Bentham's views of the problems with legal fiction, in that they were generalisations rather than specifics.

\section{Vocabulary of Fiction}

Bentham wrote of representing either the motion or rest of certain fictional bodies. He observed that a fiction would be adopted by means of an innocent falsehood. He explained that the mind imagined imaginary beings and gave them proper names, as if they existed in reality. He exemplified this with the imagining of an automaton, ${ }^{9}$ looking like a man, and playing an organ. The observing person viewed this automaton from an imaginary distance, and through a kind of mistake, considered it as the viewing of an organist. ${ }^{10}$ Bentham extended the explanation by showing how this kind of fictitious entity could become a fraudulent proposition as one element of a legal argument. Then, the lawyer only had to assess, with substantiating evidence, the probability of the fictitious proposition's truth. ${ }^{11}$ Applying a balance of probability test, a fiction ultimately might be judged as true, despite the fact it was false.

\section{Technique of Definition}

Many legal theorists have commented on the common law's relative absence of precisedefinitions and the courts' preferences for mere descriptions. ${ }^{12}$ However, for Bentham, definition per genus et differentiam ${ }^{13}$ was the proper and preferred form of definition, ${ }^{14}$ and no other would suffice.

Considering the legal fictions of right, obligation or power, the logician could find no genus of any of them. This meant definitions of legal fictive terms must be by some alternate process, necessarily not definition per genus et differentiam.Bentham suggested that a class of fictitious entities would be identified, and then the lawyer could merely associate the right, or other fiction, to this class. ${ }^{15}$ The association could be deceitful and lend itself to denunciation or false aggrandisement. In this way, a right was not a species of anything, but a right had many species distinguishable by means of the benefits which each conferred. Bentham seemed to be saying that a fictional term was more in the nature of a Platonic form.

\section{Fallacies}

Bentham devoted a separate treatise to rhetorical fallacies, which he abhorred. He succeeded in showing that they were largely an inventive perversion of words of either praise or blame. ${ }^{16}$ This kind of fallacy allowed the reader to comprehend something as possessing a quality it did not properly possess. By constant

\footnotetext{
${ }^{7}$ P Naraynam, Law of Trade Marks and Passing Off, Eastern Law House, Calcutta, 2007.

${ }^{8}$ ibid., p. 699.

${ }^{9}$ For example, in Greek mythology, Talos was an automaton represented as an artificial man of bronze, Automatones, retrieved 20 April 2015

$<\mathrm{http}: / /$ www.theoi.com/Ther/Automotones.html $>$

${ }^{10}$ CK Ogden, Bentham's Theory of Fictions, reprint from the original 1932 edition, Routledge, Oxford, 2002, p. xlii.

${ }^{11}$ ibid., pp. xliv, xlv.

${ }^{12}$ See, for example, Commissioners of Inland Revenue v. Muller \& Co Margarine (1901) AC215, per Lord MacNaghten.

${ }^{13}$ An Aristotelian pattern of definition that proceeded by citing a genus to which a term belonged, and then the difference that gave its species and so located it within the genus. The classic example was the definition of humans as rational animals. Oxford Reference, retrieved 20 April 2015, $<\mathrm{http}$ //www.oxfordreference.com/view/10.1093/oi/authority.20110803100317283>,

${ }^{14}$ CK Ogden, Bentham's Theory of Fictions, reprint from the original 1932 edition, Routledge, Oxford, 2002, p. Ixxvi.

${ }^{15}$ ibid., p. Ixxviii.

${ }^{16}$ See, for example, the encomium, discussed at Brigham Young University, The Encomium, retrieved 20 April 2015, <http://rhetoric.byu.edu/pedagogy/progymnasmata/Encomium.htm>.
} 
and habitual repetition of this praise or blame, people came to associate the good or bad quality with the thing so discussed, without examining it. ${ }^{17}$

An excellent elucidation of this process subsisted in The Encomium to Helen. ${ }^{18}$ Helen was the most notorious woman of Greece, commonly denounced. She abandoned her husband Menelaus to run away with Paris, Prince of Troy. The encomium explained it was wrong to apportion blame to Helen. After epitomising her birth and her marriage, it suggested four possible causes for why she went to Troy. They were: (a) mere chance by virtue of the gods; (b) excess of force; (c) persuasive oratory; or, (d) the exigencies of love. Each of them was overpowering and irresistible. If she were subjected to any of them, she would be blameless.Rather than praise Helen, the encomium defended her from criticism. Gorgias demonstrated that speech was too powerful a sovereign. It could either arouse or assuage fear, sorrow, pity or joy. ${ }^{19}$

However, the Encomium to Helen did not pursue this scheme. Its purpose was to use speech for showing the truth. It advised against any action based on either contingent facts or opinion, ${ }^{20}$ because speech could have the same bodily effect as drugs. Action followed inevitably and necessarily from belief. With a mastery of the art of rhetoric, the speaker could compel people to do anything he wanted, ${ }^{21}$ even without authority.

\section{Conclusion}

Ogden's introduction to Jeremy Bentham's Theory of Fictions ${ }^{22}$ suggested that legal fictions were fraudulent unless enacted by the legislature. They might thwart custom and they might divert lawful power to those who might exercise it by delusion. Such a delusion could be maintained when the judicial officer assessed a fictive proposition on the balance of probabilities. The logician might be alerted to legal fiction whenever the lawyer used juxtapositional method, instead of definition. Legal fiction could lead to rhetorical fallacies, such as either implied denunciation or false promotion.

\section{Bibliography}

[1] Automatones, retrieved 20 April 2015, <http://www.theoi.com/Ther/Automotones.html>,

[2] Cicero, Rhetorica Ad Herennium, Harvard University Press, Cambridge, 2004.

[3] Commissioners of Inland Revenue v. Muller \& Co Margarine (1901) AC215, per Lord MacNaghten.

[4] Brigham Young University, The Encomium, retrieved 20 April 2015,

$<$ http://rhetoric.byu.edu/pedagogy/progymnasmata/Encomium.htm>,

[5] Gorgias, Encomium of Helen, D M MacDowell, ed., Bristol Classic Press, London, 2005.

[6] Hegel, GWF, Lectures on the Philosophy of Religion, PC Hodgson, ed, RF Brown, PC Hodgson, \& JM Stewart, trans, 3 vols, University of California Press, Berkeley and Los Angeles, 1984-87.

\footnotetext{
${ }^{17}$ CK Ogden, Bentham 's Theory of Fictions, reprint from the original 1932 edition, Routledge, Oxford, 2002, p. cxxxvi.

${ }^{18}$ Gorgias, Encomium of Helen, D M MacDowell, ed., Bristol Classic Press, London, 2005.

${ }^{19}$ ibid., p. 12.

${ }^{20}$ ibid., p. 14.

${ }^{21}$ ibid., p. 15.

${ }^{22}$ CK Ogden, Bentham 's Theory of Fictions, reprint from the original 1932 edition, Routledge, Oxford, 2002, pp. ix-clii.
} 
G Lilienthal, 'Book Review- Bentham's Theory of Fictions', UUMJLS, vol. 6, no. 1, 2015, pp. 041-044.

[7] Naraynam, P,Law of Trade Marks and Passing Off, Eastern Law House, Calcutta, 2007.

[8] Ogden, CK, Bentham's Theory of Fictions, Routledge, Oxford, 2001.

[9] Oxford Reference, retrieved 20 April 2015.

<http://www.oxfordreference.com/view/10.1093/oi/authority.20110803100317283>,

[10] University of North Carolina's Writing Centre, Books Reviews,

$<\mathrm{http}$ ://writingcenter.unc.edu/handouts/book-reviews/ $>$. 